\title{
Fertility versus disease resistance, a hard choice
}

\author{
Rebecca Bart, ${ }^{1}$ Pamela Ronald, ${ }^{1}$ and Sarah Hake ${ }^{2,3}$ \\ ${ }^{1}$ Department of Pathology, University of California, Davis, California 95616, USA; ${ }^{2}$ Plant Gene Expression Center, United \\ States Department of Agriculture-Agricultural Research Service, Albany, California 94710, USA
}

Who among us has not heard the phrase, all good things come at a cost. Luckily, the cost/benefit scenarios that we face day to day are generally minor (extra piece of cake or a slim figure) compared with having to choose between the opportunity to have children and disease immunity. The work by Wang and colleagues (Chu et al. 2006) brings into light this exact conundrum in the plant world. The authors demonstrate a trade-off between fertility and pathogen defense, depending on levels of expression of the xa13 gene.

\section{Use of natural variation to clone disease resistance genes}

Plants have acquired a myriad of subtle tricks to deal with their surroundings. Whether it is capturing sunlight, searching for water, or avoiding being eaten, they have evolved numerous signaling mechanisms and specialized cell types to deal with their world. Most striking are the ways they have learned to deal with pests and disease. Some plants use volatiles to signal the enemy of the herbivore that is on the attack (Kessler and Baldwin 2001). Others are resilient due to spines, toxic compounds, or an impervious cuticle. Still others play a cat and mouse game of evolution, learning to recognize the disease, then sealing it off in sacrificial death of the infected cells. The rapid evolution of these disease agents (notably bacteria, fungi, and viruses) means that the plant is often quickly outwitted and loses resistance.

Xanthomonas oryzae pv. oryzae (Xoo), the causal agent of bacterial leaf blight, is the most devastating bacterial disease in Asia and Africa and is now known to occur in Australia, the United States, and South America (Jones 1988). Fortunately for the rice plant and those of us that eat rice, plants have evolved resistance genes to combat this devastating disease. Cloning of five of these genes has been previously described (Song et al. 1995; Yoshimura et al. 1998; Iyer and McCouch 2004; Sun et al. 2004; Gu et al. 2005). In this issue, Wang and colleagues (Chu et al. 2006) describe their recent success at isolating a resistance gene to Xoo that has a surprise role in fertility.

\footnotetext{
${ }^{3}$ Corresponding author.
}

E-MAIL maizesh@nature.berkeley.edu; FAX (510) 559-5678. Article and publication are at http://www.genesdev.org/cgi/doi/10.1101/ gad.1437706
Wang and her group used a mapping population constructed between near-isogenic lines IR24 carrying Xa13, and IRBB13 carrying xa13, to narrow the position of $\mathrm{Xa13}$ to a $9.2-\mathrm{kb}$ region. Within this interval was a single predicted gene. They confirmed that it was the soughtafter gene by transforming the dominant allele, Xa13, into IRBB13, the resistant host. The resulting transgenic lines carrying the Xa13 allele were susceptible. Comparison of the IRBB13 and IR24 versions of XA13 revealed one amino acid difference. To determine whether this difference was the key between susceptibility and resistance, they sequenced $x a 13$ and $X a 13$ from 10 additional varieties. Some of the $x a 13$ and Xa13 alleles had identical amino acid sequences, suggesting that the difference between susceptibility and resistance lay outside the coding sequence.

The group (Chu et al. 2006) then analyzed the promoter region of Xa13/xa13 from seven susceptible and 11 resistant rice lines. Various differences were found that were not allele specific, but all 11 xa13 lines had insertions, deletions, or substitutions within an 18-base-pair (bp) region, $70 \mathrm{bp}$ upstream from the start of transcription. They also showed that transcript levels of $\mathrm{Xa13}$ are dramatically increased upon infection, going up sixfold at 8 $\mathrm{h}$ and 47 -fold at $72 \mathrm{~h}$. Such an induction does not occur in an xa13 background. Other susceptible or resistant lines showed a similar trend. Thus, this 18-bp region is likely to be responsible for induction of gene expression of Xa13 but not xa13 alleles. Silencing of either xa13 or Xa13 by RNA interference (RNAi)-enhanced the resistance, supporting the hypothesis that high levels of expression of this gene are detrimental to the plant.

The XA13 sequence does not resemble the product of any previously identified resistance gene, but does show $50 \%$ amino acid identity to the product of a nodulin MtN3 gene that is induced by Rhizobium in legume nodule development (Gamas et al. 1996). Wang and colleagues suggest that XA13 encodes a modulator of bacterial invasion. Indeed, the bacteria grow nearly 2000fold better in plants expressing Xa13 than in the xa13 plants by $14 \mathrm{~d}$ after inoculation. Another disease-resistance allele that is inherited recessively is mlo in barley. The dominant Mlo allele encodes a membrane protein that is thought to function as an entry portal for successful pathogenesis of fungal pathogens as it accumulates at sites of fungal penetration (Bhat et al. 2005). Although 
XA13 and MLO proteins show no similarity, they may carry out similar tasks. Xoo invades rice plants through wounds and lives in the vascular system (Huang and De Cleene 1989) thus enhanced expression in membranes of these cells could lead to infection. In fact, XA13 protein localizes to the plasma membrane in callus bombardment experiments and GUS staining shows it is expressed in parenchyma cells surrounding the vascular cells of leaves. It is therefore in a perfect position to enhance bacterial invasion.

\section{XA13 is essential during pollen development}

A question that immediately comes to mind is: Why is Xa13 maintained if it makes the plant more susceptible? Interestingly, in the absence of pathogen infection, both alleles are expressed at low levels in leaves but at high levels in panicles (flower-bearing structures) and anthers, the male reproductive structures. Examination of the RNAi plants showed a loss of fertility that was correlated with loss of XA13 expression (Fig. 1). The finding that XA13 is required for fertility explains why expression of the dominant allele has been maintained. It also highlights the selective advantage of the recessive xa13 alleles, in which high levels of expression exists in panicles, but no pathogen induction occurs.

An understanding of the fertility defect in XA13 RNAi plants requires some understanding of plant sex. Anthers produce pollen, which contain sperm cells, and carpels produce embryo sacs, which contain the egg cell. Meiosis occurs in both anthers and carpels and is followed by mitotic divisions for both the microspore (male spore) and megaspore (female spore). The unicellular microspore divides asymmetrically to produce a generative cell within the cytoplasm of the vegetative cell. The gen-

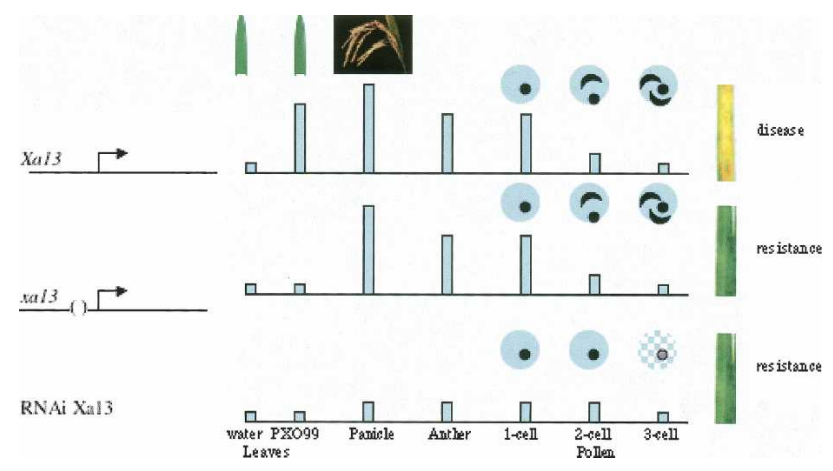

Figure 1. Xa13 expression and consequence. On the left is a schematic of the difference between $x a 13$ and Xa13 promoters. In the middle is a representation of expression levels. Xa13 leaves (green oblongs) that are treated with PX099 pathogenic bacteria express high levels of transcript compared with water control and xa13 leaves. The expression of Xa13 upon infection leads to disease as shown by a chlorotic (yellow) leaf at the far right. Transcript levels are high in panicles (shown in photo) and anthers and decrease during stages of pollen development (represented as blue circles that progress from unicellular to bicellular to tricellular). RNAi plants have increased resistance but also increased sterility due to a failure to progress from the unicellular stage of pollen. erative cell undergoes a second round of division to produce a tricellular cell containing two sperm cells and the vegetative cell (Fig. 1). One sperm cell will fertilize the egg and the other will fertilize the central cell, thus producing the endosperm. The vegetative cell produces the pollen tube for fertilization (McCormick 2004; Ma et al. 2005).

Possible clues for a role for XA13 in fertility come from the timing of the defect in XA13 RNAi plants and in situ expression patterns. Pollen from RNAi plants looks normal at the unicellular stage but often fails to progress beyond this stage. At a time when tricellular pollen is visible in controls, RNAi lines show unicellular microspores or degenerating pollen grains. Thus, it appears that XA13 is needed for the mitotic divisions of the pollen. Other male sterile mutants have been described that show normal meiosis but are blocked during microspore mitotic divisions (Ma et al. 2005). Similar phenotypes have also been found in plants that carry chromosomal defects (Kindiger et al. 1991). It will be important to determine whether XA13 is also expressed at high levels in carpels and whether there is any lack of fertility in female transmission.

The timing of expression fits with a requirement for XA13 to progress through pollen development. XA13 is abundant in the tapetum, the sporophytic nutritive tissue that surrounds the developing unicellular microspore, and in the unicellular pollen. By the time the pollen is tricellular, expression has disappeared except for some trace in the vascular tissue. Thus, XA13 transcripts appear at stages before the defect is visible. Although this study describes the first disease-resistance gene that is also required for pollen development, other examples exist of genes expressed during pollination or fertilization that are also up-regulated by stress (Lan et al. 2005).

\section{Rice disease-resistance genes}

xa13 belongs to a broad family of plant genes known as resistance ( $R$ ) genes. $R$ genes have been identified from a variety of plant species and provide resistance to all groups of pests and pathogens (insects, bacteria, fungi, viruses) (Kaloshian 2004). Of the $\sim 30$ Xoo targeting $R$ genes identified in rice (Makino et al. 2006), two-thirds function as dominant resistance alleles and the others provide resistance when recessive, similar to xa13. Of the five Xoo R genes that were previously cloned, only resistance conferred by the dominant $\mathrm{Xa27}$ gene is controlled at the level of transcriptional regulation (Gu et al. 2005). Like xa13, Xa27 and xa27 encode identical proteins but have differences in the promoter. Xa27 encodes a protein of 113 amino acids that does not resemble any other R gene and has no significant sequence similarity to any proteins of known function. In contrast to Xa13, in which the susceptible allele is induced by pathogen infection, the resistant allele of $\mathrm{Xa27}$ is expressed after challenge with the pathogen.

Recessively inherited resistance does not always follow the pattern established with xa13 and mlo; i.e., resistance by avoidance of pathogen. For example, xa5, the first Xoo targeting recessive $\mathrm{R}$ allele to be cloned, is constitutively expressed at the same level as the dominant 
susceptible allele, $\mathrm{Xa5}$, and neither allele is induced or suppressed in response to Xoo (Iyer and McCouch 2004; Jiang et al. 2006). xa5 was identified as a natural mutation conserved among different varieties of rice and encodes the $\gamma$ subunit of transcription factor IIA (TFIIA $\gamma$ ). The proteins encoded by the recessive and dominant alleles differ by a single amino acid change from valine to glutamic acid, representing a change from hydrophobic to hydrophilic at that location. Jiang et al. (2006) suggest that this change disrupts a protein-protein interaction necessary for disease.

Perhaps the most striking aspect of the xa13 study is the unusual connection between disease resistance and pollen development. Although these topics are generally thought to be distinct, other examples exist where development and disease intersect. For example, resistance controlled by $\mathrm{Xa21}$, which encodes a receptor-like kinase with a transmembrane domain and a leucine-rich repeat (RLK-LRR) extracellular domain (Mazzola et al. 1994; Song et al. 1995; Wang et al. 1998) is developmentally regulated. Century et al. (1999) showed that the Xa21 transcript is expressed at a constant low level throughout development and is not induced by pathogen infection; however, disease resistance increases with age in Xa21-expressing plants. Interestingly, the stability of the $\mathrm{XA} 21$ protein itself is developmentally regulated, and is associated with proteolytic activity during development. Similarly, Chern et al. (2005) showed that overexpression of the rice gene $N R R$, a negative regulator of resistance, affects both resistance and development. As a rice plant matures, basal levels of resistance increase (Koch and Mew 1991). In plants overexpressing NRR, this agerelated resistance was compromised. This decrease in agerelated resistance correlated with a decrease in fertility. Taken together, these studies show that development and disease resistance are often intimately connected.

\section{Acknowledgments}

The researchers are supported by NIH grant GM-55962 (to P.R. and R.B.) and the USDA-ARS (to S.H.).

\section{References}

Bhat, R.A., Miklis, M., Schmelzer, E., Schulze-Lefert, P., and Panstruga, R. 2005. Recruitment and interaction dynamics of plant penetration resistance components in a plasma membrane microdomain. Proc. Natl. Acad. Sci. 102: 3135-3140.

Century, K.S., Lagman, R.A., Adkisson, M., Morlan, J., Tobias, R., Schwartz, K., Smith, A., Love, J., Ronald, P.C., and Whalen, M.C. 1999. Short communication: Developmental control of Xa21-mediated disease resistance in rice. Plant J. 20: 231-236.

Chern, M., Canlas, P.E., Fitzgerald, H.A., and Ronald, P.C. 2005. Rice NRR, a negative regulator of disease resistance, interacts with Arabidopsis NPR1 and rice NH1. Plant J. 43: 623-635.

Chu, Z., Yuan, M., Yao, J., Ge, X., Yuan, B., Xu, C., Li, X., Fu, B., Li, Z., Bennetzen, J.L., et al. 2006. Promoter mutations of an essential gene for pollen development result in disease resistance in rice. Genes \& Dev. (this issue).

Gamas, P., Niebel Fde, C., Lescure, N., and Cullimore, J. 1996. Use of a subtractive hybridization approach to identify new Medicago truncatula genes induced during root nodule development. Mol. Plant Microbe Interact. 9: 233-242.
Gu, K., Yang, B., Tian, D., Wu, L., Wang, D., Sreekala, C., Yang, F., Chu, Z., Wang, G.L., White, F.F., et al. 2005. R gene expression induced by a type-III effector triggers disease resistance in rice. Nature 435: 1122-1125.

Huang, J.S. and De Cleene, M. 1989. How rice plants are infected by Xanthomonas campestris pv. oryzae. In Bacterial blight of rice, pp.31-42. International Rice Research Institute, Manila.

Iyer, A.S. and McCouch, S.R. 2004. The rice bacterial blight resistance gene xa5 encodes a novel form of disease resistance. Mol. Plant Microbe Interact. 17: 1348-1354.

Jiang, G.H., Xia, Z.H., Zhou, Y.L., Wan, J., Li, D.Y., Chen, R.S., Zhai, W.X., and Zhu, L.H. 2006. Testifying the rice bacterial blight resistance gene xa5 by genetic complementation and further analyzing xa5 (Xa5) in comparison with its homolog TFIIA $\gamma 1$. Mol. Genet. Genomics 275: 354-366.

Jones, R. 1988. New disease hits Texas. Rice J. Feb: 4-5.

Kaloshian, I. 2004. Gene-for-gene disease resistance: Bridging insect pest and pathogen defense. J. Chem. Ecol. 30: 2419-2438.

Kessler, A. and Baldwin, I.T. 2001. Defensive function of herbivore-induced plant volatile emissions in nature. Science 291: 2141-2144.

Kindiger, B., Beckett, J.B., and Coe Jr., E. 1991. Differential effects of specific chromosomal deficiencies on the development of the maize pollen grain. Genome 34: 579-594.

Koch, M.F. and Mew, T.W. 1991. Effect of plant age and leaf maturity on the quantitatve resistance of rice cultivars to Xanthomonas campestris pv. oryzae. Plant Dis. 75: 901-904.

Lan, L., Li, M., Lai, Y., Xu, W., Kong, Z., Ying, K., Han, B., and Xue, Y. 2005. Microarray analysis reveals similarities and variations in genetic programs controlling pollination/fertilization and stress responses in rice (Oryza sativa L.). Plant Mol. Biol. 59: 151-164.

Ma, L.S., Pan, B.R., Li, W.Z., and Guo, S.Y. 2005. Improved citation status of World Journal Gastroenterology in 2004: Analysis of all reference citations by WJG and citations of WJG articles by other SCI journals during 1998-2004. World I. Gastroenterol. 11: 1-6.

Makino, S., Sugio, A., White, F., and Bogdanove, A.J. 2006. Inhibition of resistance gene-mediated defense in rice by Xanthomonas oryzae pv. oryzicola. Mol. Plant Microbe Interact. 19: 240-249.

Mazzola, M., Leach, J.E., Nelson, R., and White, F.F. 1994. Analysis of the interaction between Xanthomonas oryzae pv. oryzae and the rice cultivars IR24 and IR-BB21. Phytopathology 84: 392-397.

McCormick, S. 2004. Control of male gametophyte development. Plant Cell 16 (Suppl): S142-S153.

Song, W.Y., Wang, G.L., Chen, L.L., Kim, H.S., Pi, L.Y., Holsten, T., Gardener, J., Wang, B., Zhai, W.X., Zhu, L.H., et al. 1995. A receptor kinase-like protein encoded by the rice disease resistance gene, Xa21. Science 270: 1804-1806.

Sun, X., Cao, Y., Yang, Z., Xu, C., Li, X., Wang, S., and Zhang, Q. 2004. Xa26, a gene conferring resistance to Xanthomonas oryzae pv. oryzae in rice, encodes an LRR receptor kinaselike protein. Plant J. 37: 517-527.

Wang, G.L., Ruan, D.L., Song, W.Y., Sideris, S., Chen, L., Pi, L.Y., Zhang, S., Zhang, Z., Fauquet, C., Gaut, B.S., et al. 1998. Xa21D encodes a receptor-like molecule with a leucine-rich repeat domain that determines race-specific recognition and is subject to adaptive evolution. Plant Cell 10: 765-779.

Yoshimura, S., Yamanouchi, U., Katayose, Y., Toki, S., Wang, Z.X., Kono, I., Kurata, N., Yano, M., Iwata, N., and Sasaki, T. 1998. Expression of Xa1, a bacterial blight-resistance gene in rice, is induced by bacterial inoculation. Proc. Natl. Acad. Sci. 95: 1663-1668. 


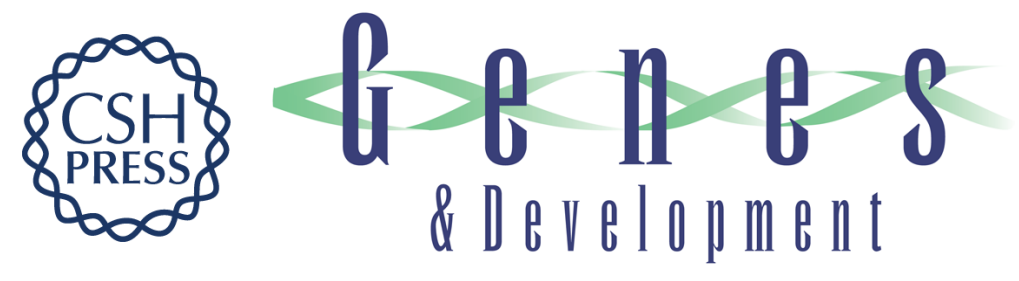

\section{Fertility versus disease resistance, a hard choice}

Rebecca Bart, Pamela Ronald and Sarah Hake

Genes Dev. 2006, 20:

Access the most recent version at doi:10.1101/gad.1437706

Related Content Promoter mutations of an essential gene for pollen development result in disease resistance in rice

Zhaohui Chu, Meng Yuan, Jialing Yao, et al.

Genes Dev. May , 2006 20: 1250-1255

References This article cites 20 articles, 6 of which can be accessed free at:

http://genesdev.cshlp.org/content/20/10/1215.full.html\#ref-list-1

Articles cited in:

http://genesdev.cshlp.org/content/20/10/1215.full.html\#related-urls

\section{License}

Email Alerting Receive free email alerts when new articles cite this article - sign up in the box at the top Service right corner of the article or click here.

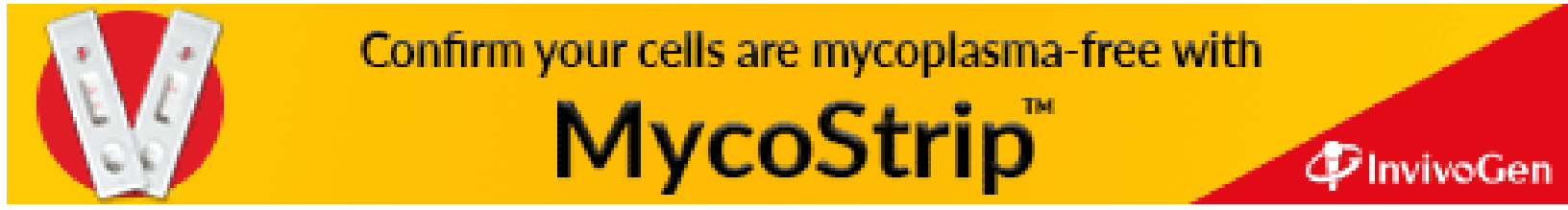

